\title{
МЕТОДИКА
}

УДК 376.04.016-053.8:811.111

\section{ENGLISH LANGUAGE TEACHING IN HETEROGENEOUS GROUPS OF ADULTS: CHALLENGES AND ADVANTAGES}

\author{
Renata Botwina \\ University of Warsaw \\ 4, Szturmowa St., Warsaw, Poland, 02-678 \\ r.botwina@uw.edu.pl
}

The present study investigates the specifics of English language teaching at the Department of Ukrainian Studies of the University of Warsaw in the context of dealing with heterogeneous groups of adults. The focus of the paper is on the problems and advantages of teaching English to Poles, Ukrainians, Belarusians and occasionally students participating in the Erasmus plus program. Based on the theory of the authors, such as Ur (2005), Scrivener (2005) and Harmer (1998), the paper discusses in detail the case of the Department of Ukrainian Studies of the University of Warsaw. On the basis of her findings, pedagogical implications are discussed and recommendations for further research are suggested.

Keywords: English language teaching, heterogeneous groups, mixed-ability classes, adult learners, language interference

Introduction. The Department of Ukrainian Studies of the University of Warsaw is the oldest Ukrainian research center in Poland and Western Europe. In 2013 it celebrated the sixtieth anniversary of its founding. Its traditions, however, began in the 20s and 30 s of the twentieth century and are closely connected with Ivan Ohijenko, Roman Smal-Stocki and Myron Korduba [14, p. 44]. Warsaw's Ukrainian Department has always combined tradition with modernity so as to make students competitive in job markets by giving them an opportunity to gain insights into Ukrainian history, culture and literature and acquire Ukrainian, English and Russian languages.

In 2012 the curriculum of the Department was enriched with two languages - Russian and English - which along with Ukrainian are taught intensively during the course of studies. At present, BA students attend practical English classes (360 hours per 6 semesters) and translation workshops (30 hours during semester 6). MA students attend practical English classes (150 hours per 4 semesters), language of tourism (30 hours per 3 semesters), Business English (30 hours during the 4th semester) and selected topics of English literature and culture (30 hours during the 4th semester). Upon BA studies completion students receive B2 level of the English language. After finishing MA studies students receive $\mathrm{C} 1$ level of the English language according to the Common European Framework of Reference for Languages (CEFRL).

Theoretical background. When it comes to English language teaching at the Department of

(C) R. Botwina, 2017 
Ukrainian studies, tutors have to deal with heterogeneous groups defined as "having different kinds of learners in it, as opposed to a "homogeneous" class, where the learners are similar" [19, p. 273]. Heterogeneous classes are sometimes called mixed-ability classes, which, according to Penny Ur, can be misleading: "The term "mixed-ability", however, implies the important difference between members of a mixed class in their language-learning ability, but this is not necessarily so. Even if the main observed difference between them is in the amount of language they know, this may have its roots in all sorts of other reasons besides ability (previous teaching, motivation, etc.). And there are plenty of other differences between learners that need to be taken into account by a teacher: preferred learning style, personality, interests, cultural background - to name only a few. Thus the term "heterogeneous" - composed of different kinds of people - is I think more suitable in defining such classes" [19, p. 273].

Scrivener gives more details when he says that "[...] calling a class "pre-intermediate" can make sense - it's a useful general classification that gives a reasonable overall picture of what they might know and what they might be able to do" [15, p. 68]. Thus, the term 'heterogeneous' implies more than just students' language proficiency level and suggests important differences which need to be taken into consideration when teaching such a group.

The practice of assigning mixed groups of students to heterogeneous classrooms stems, first of all, from economical reasons (conducting classes for just a few students representing the same language proficiency would be too costly). Secondly, there is a popular education assumption that positive interdependence develops when students of varying achievement work together and help each other reach educational goals. Both reasons are taken into consideration when assigning students to heterogeneous groups at the Department of Ukrainian Studies: 1) students' language proficiency discrepancy is usually too big and would require too many groups; 2) being a part of an international group, students learn to cooperate and are encouraged to learn from and about each other.

Experienced teachers know that working with homogeneous groups can be both rewarding and problematic. Traditionally, students and teachers may prefer to be part of a homogeneous classroom where they see an educational advantage or just feel more comfortable working with peers of similar ability. Another problem is that advanced students in a heterogeneous group may at times feel forced into a leadership role they do not want. Boredom can also appear in heterogeneous groups - rather than learning at their own speed, more advanced students are often forced to slow down to assist their peers. What is more, being part of a homogeneous group, weaker students may lose confidence falling behind and ending up criticized for slowing the rate of the whole class or group. As a result, unmotivated or academically challenged students may end up ignored rather than assisted by their peers. This puts a big pressure on the teacher who needs to remain aware and recognize when a heterogeneous group does not function properly for a student at any level. Additionally, teachers should support advanced students by supplying additional academic challenges and help students who fall behind get the assistance they need to catch up. All in all, it is difficult to activate all the students in the heterogeneous class.

Nevertheless, working with homogeneous groups can be rewarding. Penny Ur argues that such classes provide "a richer pool of human resources" than less mixed classes. She claims that "the individuals have between them far more life experience and knowledge, more varied options, more interests and ideas - all of which can be used in classroom interaction" [19, p. 276]. This enhances an educational value and allows for cooperation between different kinds of people: students get to know each other's value, personalities and cultures and thereby increase 
their own knowledge and awareness of others. Moreover, students in heterogeneous classes are somehow forced to help themselves by teaching each other and working together. Consequently, peer- teaching and collaboration are likely to emerge in such groups. Last but not least, these classes can be seen as more challenging and interesting to teach, providing a greater opportunity for creativity, innovation and general professional development [19, p. 305].

Specifics of ELT at the Department of Ukrainian Studies of the University of Warsaw. Students studying at the Department of Ukrainian Studies of the University of Warsaware are mainly Poles, Ukrainians and occasionally Belarusians. Additionally, each semester the classes are joined by a few students from abroad participating in the Erasmus plus program, which makes groups really international. Choosing Ukrainian studies, Poles are usually driven by a desire to learn new languages (Ukrainian and Russian) planning a future career of a professional translator. Students from Ukraine, in turn, undertake studies in Poland seeking primarily a better future for a difficult situation in Ukraine forces them to leave the country. Thus, Ukrainian studies of the University of Warsaw seem to be a perfect choice for them bearing in mind the fact that the great majority of students from Ukraine already speak Ukrainian and Russian fluently. In their case, English is an added attraction as during the studies at the Department they have an opportunity to improve their English language skills or learn it from scratch. As a result, there is a growing interest in the Department of Ukrainian Studies at the University of Warsaw among students from Ukraine who increasingly apply for BA studies to continue the studies till the end of the MA cycle. ${ }^{1}$

Upon their arrival in Poland, Ukrainian students have to face many problems. As a rule, a secondary school graduate in Ukraine is 17 years old. Becoming a student in a foreign country at such a young age undoubtedly causes a shock since young people have to adapt to a new environment, a different language and various academic duties. This can be very stressful given that often students from Ukraine barely speak Polish. They often feel lost and homesick trying to cope with the mundane reality of academic life in a foreign country.

As far as practical English classes are concerned, the most common problem emerging from the very beginning is the students' unequal level of language proficiency. Students from Poland finish secondary schools with B1 / B2 level of English. This situation is drastically different for young people from Ukraine or Belarus - their level is usually A1 / A2, - and often they are beginners or false beginners. Even if the graduates of Ukrainian secondary schools did attend English classes at school, they have big shortcomings and their knowledge is rather theoretical. They often report that in Ukraine English language classes are conducted in accordance with the Grammar-Translation Method which consists in translating texts from English into Ukrainian and copying new words from the blackboard. For the same reason, Ukrainians have a big problem with listening comprehension exercises, which for the majority are a novelty.

Translation workshops are also problematic. This course is introduced during the final semester of undergraduate studies when theoretically the level of students should approach B2. In practice, this subject is a big challenge not only for students but also for teachers. During the course, students are supposed to translate specialist texts from Polish into English and vice versa. For Polish students English is a foreign language but for Ukrainians and Belarusians both Polish and English are foreign. As a matter of fact, they have difficulties choosing correct lexical equivalents. What is more, they do not know how to use specialist dictionaries and lack

${ }^{1}$ The percentage of Ukrainian students studying at the Department of Ukrainian Studies at the University of Warsaw in the academic year 2016/2017: BA studies - 27\%, MA studies - 59\%. 
knowledge of appropriate lexical collocations. Consequently, students" poor language skills result in making basic mistakes both in Polish and English. Unfortunately, much too often discouraged students use Google Translate, taking its translation versions for granted. It goes without saying that conducting such a subject is very challenging for teachers who, on the one hand, have to follow the curriculum objectives and, on the other hand, have to realistically measure the students skills and abilities.

MA students attend subjects called "language of tourism" (introduced during the 3rd semester) and "Business English" (last semester). These subjects assume some knowledge of the specialized vocabulary and mechanisms related to the fields of business, foreign trade, customer service, tourism, hotel management, etc. The main problem during these subjects is Ukrainian and Belarusian students' resistance to speak. They are very reluctant when it comes to oral presentations or role play games (e.g. business interviews, travel scenarios, etc.). Students from Ukraine and Belarus usually stick to ready-made presentations which they learn by heart or simply read aloud to the rest of the group. It is very difficult to break this fixed model because students explain that this is how they learned English at school, memorizing English texts or reading them in front of the class. Therefore, teachers have to put a special emphasis on practicing speaking and provoking skilful conversations that involve both speaking and listening comprehension. As a result, students from Ukraine and Belarus need time to get accustomed to communication exercises (role plays, games, debates etc.), which in the beginning they find "strange" and "artificial".

When teaching heterogeneous groups another serious problem is related to the choice of a coursebook. As it was already mentioned, the range of language levels in one group may vary from A1 to B2 which makes it difficult to concentrate on one coursebook suitable for all students in one group. Typical coursebooks are written in English and focus on practicing both receptive and productive skills. Poles have no problems understanding instructions in English since they have been using such coursebooks since primary school. Students from Ukraine have problems understanding instructions in English due to the fact that they are used to coursebooks where instructions are given in Ukrainian. As a result, teachers have to introduce supplementary materials to cater for all the members of the group. Additionally, Harmer suggests to "do different tasks with the same material" [11, p. 127]. On the one hand, this allows for additional time for some students who have not finished the task. On the other hand, boredom is avoided for those who have already finished the task. Moreover, teachers should always be ready to provide more advanced students with a spare activity or an extension of the original task.

Results and Discussion. Language interference, known as L1 interference, linguistic interference, language transfer and cross meaning, can be observed during all courses of English conducted at the Department of Ukrainian Studies. The term refers to the situation when speakers learning a target language apply knowledge from their L1 to L2. Dulay et al. define interference as "the automatic transfer, due to habit, of the surface structure of the first language onto the surface of the target language" [7]. Lott defines interference as "errors in the learner's use of the foreign language that can be traced back to the mother tongue" [13, p. 256]. Ellis, in turn, refers to interference as "transfer", which is "the influence that the learner's L1 exerts over the acquisition of an L2" [8, p. 51]. He claims that transfer is governed by learners' assumptions about what is transferable and by their proficiency in L2. Consequently, while learning a target language, learners may construct their own interim rules based on the use of their L1 knowledge $[18 ; 16 ; 8]$.

The situation when a learner"s understanding of one language affects his or her understanding 
of another language results in language transfer. Two types of language transfer are distinguished: there can be negative transfers, known as interference, when the understanding of one language affects the understanding of another language. Alternatively, positive transfers take place when the learner's knowledge of L1 can aid in developing skills for L2. Thus, language interference is the effect of language learners" $\mathrm{L} 1$ on their production of the language they are learning. In other words, the speaker's L1 influences his/her second or/and his/her foreign language.

Language interference may affect different aspect of language: grammar, phonetics, vocabulary, spelling, etc. It is widely considered as one of error sources (negative transfer). According to the contrastive analysis [5], the greater the differences between the two languages, the more negative the effects of interference are likely to be. Hence, there is a close relationship between the two languages: L1 and L2. Albert and Obler claim that people show more lexical interference on similar items [1]. So it may follow that languages with more similar structures (e.g. English and German) are more susceptible to mutual interference than languages with fewer similar features (e.g. English and Chinese). On the other hand, we might also expect more learning difficulties and thus more likelihood of performance interference regarding the points in L2 which are more distant from L1, as the learner would find it difficult to learn and understand a completely new and different usage. As a result, the learner resorts to L1 structures for help $[18 ; 7 ; 4 ; 10 ; 3 ; 6]$.

Berthold et al. define phonological interference as items including foreign accent such as stress, rhyme, intonation and speech sounds from L1 influencing L2 [2]. Grammatical interference is defined as L1 influencing L2 in terms of word order, use of pronouns and determinants, tense and mood, etc. Interference at a lexical level involve borrowing of words from one language and converting them to sound more natural in another and orthographic interference includes the spelling of one language altering another.

As far as students from Ukraine and Belarus are concerned, the following transfer resulting from linguistic interference can be observed at the phonetic and grammatical levels:

1. Substituting sounds: $s$ instead of th: $[\theta]$ vs [ð]; [w] vs [ v]; students often say sank you instead of thank you.

2. Omitting sounds that should be clearly articulated: eg. saying majn instead of mind (majnd).

3. Adding sounds where they should not be heard: eg the word table is pronounced [teibul] instead of [teibl]

4. Differentiating between long vowels [i:] and short vowels [i]: ship and sheep are pronounced in the same way.

5. Differentiating between vowels $/ æ /, / \mathrm{e} /$ and $/ \varepsilon /$ : the words bet and $b a t$ sound the same.

These are just a few examples illustrating the level of linguistic interference characteristic for students from Ukraine and Belarus. Of course, language transfer also affects Poles but, bearing in mind the fact that their starting language proficiency level is better, the phenomenon exists on a lesser scale. Komorowska claims that the most practical approach to phonetic shortcomings is to "train pronunciation to a degree that will allow communication" [12, p. 213]. For this reason, students from Ukraine and Belarus attend additional English language classes to complement their phonetics and phonology deficiencies. Students learn phonetic symbols, practice pronunciation of short / long vowels, problematic consonants and transcription. Students also receive supplementary exercises to practice listening comprehension in various registers, which also allows them to work out appropriate listening strategies.

Conclusion. Although teaching homogeneous groups is really challenging, it does not 
have to be problematic. When teaching such groups, we need to remember to constantly notice and respond to students' feedback in order to "adjust and redirect work moment by moment to make it as effective for each individual as possible" [15, p. 69]. To do this, topics, methods and texts should be varied to cater for all students in the group. Teachers should propose interesting activities to hold interest and keep everyone participating even if the content is not that challenging in terms of the language proficiency. Moreover, collaboration should be encouraged, so that learners work cooperatively and peer-teach even when the teacher cannot directly interact with each student. What is more, learners should be allowed some choice in what tasks or material they use and how they do it. Penny Ur suggests introducing personalisation when teaching a homogeneous group: "whenever possible, design or adapt tasks in order to allow for different individual responses, based on learners' own experience, opinions or imagination" [19, p. 275]. All of the above suggestions are successfully implemented when teaching English at the Department of Ukrainian Studies of the University of Warsaw. To reduce the level of language interference and negative transfers, students attend additional classes where they learn English phonetics, do listening comprehension exercises and practice speaking skills, which makes a great contribution to their better communication in the target language.

\section{References}

1. Albert M. L. The Bilingual Brain: Neuropsychological and Neurolinguistic Aspects of Bilingualism / M. L. Albert, L. K. Obler. - New York : Academic Press, 1978. - 304 p.

2. Berthold M. Bilingualism \& Multiculturalism: Study Book / M. Berthold, F. Mangubhai, K. Batorowicz. - Queensland : Distance Education Centre, Toowoomba, QLD, 1997. - 240 p.

3. Bialystok E. Communication Strategies / E. Bialystok. - Oxford : Basil Blackwell, 1990 - 195 p.

4. Blum-Kulka S. Universals of lexical simplification // Strategies in Interlanguage Communication; [eds. C. Faerch, G. Kasper] / S. Blum-Kulka, E. A. Levenston. - London : Longman 1983. - 180 p.

5. Corder P. Strategies of communication // Strategies in Interlanguage Communication; [eds. C. Faerch, G. Kasper] / P. Corder. - London : Longman, 1983. - 230 p.

6. Dordick M. Testing for a hierarchy of the communicative interference value of ESL errors // System / M. Dordick. - 1996. - Vol. 24. - P. 299-308.

7. Dulay H. Language Two / H. Dulay, M. K. Burt, S. Krashen. - New York : Oxford University Press, 1982. $-315 \mathrm{p}$.

8. Ellis R. Second Language Acquisition / R. Ellis. - Oxford : Oxford University Press, 1997. - 147 p.

9. Ellis R. Understanding Second Language Acquisition / R. Ellis. - Oxford : Oxford University Press, 1986. $-327 \mathrm{p}$.

10. Faerch C. Plans and strategies in foreign language communication // Strategies in Interlanguage Communication; [eds. C. Faerch, G. Kasper] / C. Faerch, G. Kasper. - London : Longman, 1983. $-270 \mathrm{p}$.

11. Harmer J. How to Teach English / J. Harmer. - Harlow : Longman, 1998. - 212 p.

12. Komorowska H. Metodyka Nauczania Języków Obcych / H. Komorowska. - Warszawa : Fraszka Edukacyjna, 2005. - 204 p.

13. Lott D. Analysing and Counteracting Interference Errors in the English Language / D. Lott // Teaching Journal. - 1983. - No 37/3. - P. 256-62.

14. Mytnik I. Warszawska ukrainistyka wczoraj i dziś. Przemówienie z Międzynarodowej Konferencji Naukowej "Ukrainistyka - tradycje i współczesność" / I. Mytnik // Studia Ucrainica Varsoviensia. - 2015. - Vol. 3 (Warszawa 6 grudnia 2013). - P. 15.

15. Scrivener J. Learning Teaching / J. Scrivener. - Oxford : Macmillan, 2005. - 432 p. 
16. Seligar H. Psycholinguistic Issues in Second Language Acquisition // Issues in Second Language Acquisition, Multiple Perspectives; [ed. L. M. Beebe] / H. Seligar. - London : Newbury, 1988. $120 \mathrm{p}$.

17. Selinker L. On the use of informants in discourse analysis and "language for specific purposes" / L. Selinker // International Journal of Applied Linguistics. - 1979. - No 17. - P. 189-215.

18. Selinker L. The psychologically relevant data of second language learning // The Psychology of Second Language Learning; [eds. P. Pimsleur, T. Quinn] / L. Selinker. - London : Cambridge University Press, 1971. $-260 \mathrm{p}$.

19. Ur P. Course in Language Teaching / P. Ur. - Cambridge : Cambridge University Press, 2005. $367 \mathrm{p}$.

\title{
ВИКЛАДАННЯ АНГЛІЙСЬКОЇ МОВИ У НЕОДНОРІДНИХ ГРУПАХ ДОРОСЛИХ: ВИКЛИКИ ТА ПЕРЕВАГИ
}

\author{
Рената Ботвіна
}

Варшавський університет

вул. Штурмова 4, Варшава, Польщза, 02-678

r.botwina@uw.edu.pl

Наголошено на особливостях викладання англійської мови студентам відділення україністики Варшавського університету з погляду неоднорідних груп дорослих. Зосереджено увагу на проблемах та перевагах викладання англійської мови польським, українським та білоруським студентам, а також студентам, які навчаються за семестровими програмами міжнародної мобільності студентів Erasmus + . Визначено програмні та ресурсні особливості викладання, чинники інтерференції з рідної мови, а також можливі шляхи верифікованої оптимізації результатів навчання.

Ключові слова: викладання англійської мови, неоднорідні групи, змішані заняття, навчання дорослих, мовна інтерференція. 